\title{
HUBUNGAN KEPUASAN KERJA DENGAN TURNOVER PERAWAT DI RUMAH SAKIT AWAL BROS PANAM \\ TAHUN 2017
}

\section{(Relationship of Job Satisfaction with The Nurses Turnover In Awal Bros Panam Hospital)}

\author{
Sri Muharni * \\ * Dosen STIKes Awal Bros Batam
}

\begin{abstract}
Turnover is employees cessation from the workplace voluntarily or moved from one place to another. Data nurses turnover was supported by American Health Care Association (AHCA) survey report in 2011, which 2 million staff of hospital health in the United States obtained that 1.3 million staff $(66 \%)$ were nurses. Data nurses turnover in RSAB Panam quite high because turnover nurse January - December 2015 was $13.1 \%$ and the period of January December 2016 was 11.6. Turnover will impact to the nursing shortage staff, who will ultimately have adverse impact on hospital services, less handled patients, exhausted nurses, thus creating a return nurse turnover. The aim of this research is to find out the relationship of job satisfaction with the nurses turnover at Awal Bros Panam Hospital. This research method used descriptive correlation design with cross sectional approach. The sample in this study was all nurses with a working period of $\leq 2$ years per month of August 2017 were choosen selected using total sampling technique. The results showed that dissatisfied nurses work in RSAB Panam was 42 people (58.3\%) and turn over nurses currently high was 42 nurses (58.3\%). Based on statistical test of chi square, $p$ value = 0,027 was obtained, normally $p$ value $<0,05$, hence there was relation of job satisfaction with nurse turnover at Hospital of Awal Bros Panam 2017. This study suggested hospital management, to be able to suppressed turn over nurses through monitoring the head of the room and prevention turnover by considering the factors that caused dissatisfaction of nurses.
\end{abstract}

Keywords: Job satisfaction, turnover, nurse

\section{PENDAHULUAN}

Organisasi adalah sebagai proses penentuan, pengelompokan, dan pengaturan bermacam-macam aktivitas yang diperlukan untuk mencapai tujuan bersama (Hasibuan, 2016). Rumah sakit adalah salah satu bentuk organisasi yang bergerak dibidang perawatan kesehatan profesional yang menyediakan pelayanan dokter, perawat dan tenaga ahli kesehatan lainnya. Menurut Keputusan Menteri Kesehatan Republik Indonesia No. 340/MENKES/PER/III/2010 adalah "Rumah sakit adalah institusi pelayanan kesehatan yang menyelenggarakan pelayanan kesehatan perorangan secara paripurna yang menyediakan pelayanan rawat inap, rawat jalan dan gawat darurat".

Keberhasilan suatu organisasi rumah sakit, sangat ditentukan oleh bagaimana rumah sakit tersebut mengelola Sumber Daya Manusia (SDM) yang dimilikinya, oleh sebab itu manajemen sadar akan nilai investasi karyawan sebagai salah satu aset penting rumah sakit. SDM dapat menggerakkan sumber daya lainnya dan secara tidak langsung dapat mempengaruhi 
tingkat efisiensi dan efektifitas rumah sakit. SDM adalah kemampuan terpadu dari daya pikir dan daya fisik yang dimiliki individu, perilaku dan sifatnya ditentukan oleh keturunan dan lingkungannya, sedangkan prestasi kerjanya dimotivasi oleh keinginan untuk memenuhi kepuasannya (Hasibuan, 2016).

SDM rumah sakit yang dikenal dengan istilah tenaga kesehatan merupakan orang yang mengabdikan diri dalam bidang kesehatan serta memiliki pengetahuan dan keterampilan yang memerlukan kewenangan untuk melakukan pelayanan kesehatan (UU RI No.36 tahun 2014). Dalam UU tenaga kesehatan yang diatur dalam pasal 2 ayat (2) dengan ayat (8) Peraturan Pemerintah Nomor 32 Tahun 1996, tenaga kesehatan ini terdiri dari tenaga medis, keperawatan, kebidanan, kefarmasian, gizi, dan tenaga kesehatan lainnya. Berdasarkan data di atas, tenaga kesehatan yang paling intens memberikan pelayanan dan pengobatan kepada pasien yang ada dirumah sakit adalah perawat, karena perawat mendampingi pasien selama 24 jam.

Menurut Gillies, pada umumnya rumah sakit mempunyai sumber daya perawat sekitar $60 \%$ dari seluruh jumlah sumber daya yang ada di Rumah sakit. Berdasarkan Biro Statistik Buruh Washington DC, Amerika Serikat (Bureau of Labor Statistics, BLS) kategori tenaga kesehatan terbanyak adalah perawat dengan 2,4 juta pekerja, yang $60 \%$ diantaranya bekerja di rumah sakit (Sharon \& Nancy, 2014).

Perkembangan rumah sakit di Indonesia cukup pesat berdasarkan data Kementerian Kesehatan pada bulan Maret tahun 2013, jumlah rumah sakit di Indonesia mencapai 2.083 buah dengan jumlah perawat mencapai 220.575 orang. Berdasarkan perhitungan Kementerian Kesehatan jumlah tersebut telah mencukupi, namun secara distribusinya belum merata di seluruh Indonesia. Seringkali rumah sakit kekurangan tenaga perawat karena minimnya yang melamar atau karena perawat yang mengundurkan diri. Tenaga keperawatan yang berkualitas mempunyai sikap profesional dan menunjang pembangunan kesehatan, hal ini memberikan dampak langsung pada mutu pelayanan di Rumah sakit. Pemberdayaan sumber daya perawat mulai dari proses recruitment, seleksi, penempatan, pembinaan serta pengembangan karir harus terkelola dengan baik. Hal ini harus dilakukan semaksimal mungkin agar dapat memberikan kepuasan kerja bagi perawat dan dapat mencegah keinginan perawat untuk berpindah kerja (turnover).

Turnover adalah berhentinya seorang karyawan dari tempat kerjanya secara sukarela atau pindah dari satu tempat ke tempat lain (Saining, Hamzah \& Indar, 2011). Turnover adalah proses dimana tenaga kerja meninggalkan organisasi dan harus ada yang menggantikannya (Mathis \& Jackson, 2011). Patra dan Wibawa (2015) menyatakan bahwa turnover mengarah pada kenyataan akhir yang dihadapi oleh organisasi dimana sejumlah karyawan meninggalkan organisasi dalam periode tertentu. Diperkirakan pada tahun 2020 akan ada kekurangan 1 juta perawat di Amerika Serikat, hal ini disebabkan karena terjadinya pertumbuhan industri kesehatan yang terus menerus melebihi kebutuhan perawat yang tersedia dan peningkatan angka turnover di masa yang akan datang.

Data turnover perawat didukung oleh laporan survey American Health Care Association (AHCA) pada tahun 2011, dimana dari 2 juta staff kesehatan rumah sakit di Amerika Serikat didapatkan 1,3 juta staff (66\%) adalah perawat. Dari survey tersebut didapat data turnover tertinggi berada pada staff perawat dengan jumlah $39,5 \%$ dari jumlah turnover seluruh staff di rumah sakit. Penelitian sesuai dengan penelitian yang dilakukan $\mathrm{O}$ BrienPallas, Murphy, Shamian, Hayes (2010) dari Kanada, turnover merupakan masalah utama di rumah sakit dengan tingkat turnover rata - rata $19,9 \%$. Hal yang sama juga terjadi di Jordania, rata-rata tingkat turnover tahunan perawat mencapai $36,6 \%$.

Dari hasil suvey work Asia yang dikutip oleh Amirullah (2011) dalam penelitian Alfiyah (2013), pada tahun 2007/2008 survey yang dilakukan konsultan SDM Watson Wyatt di 11 negara Asia- Pasifik, termasuk Indonesia mengungkapkan $51 \%$ karyawan di Indonesia melakukan pindah kerja atau keluar dari satu perusahaan karena rendahnya tingkat kepuasannya dalam bekerja. Sampai saat ini belum terdapat data pasti yang membahas masalah mengenai jumlah kasus turnover di dunia. Kasus turnover juga merupakan kasus yang cukup banyak terjadi dirumah sakit swasta di Indonesia. Hasil penelitian Anik (2013) 
menyatakan bahwa turnover perawat di rumah sakit ibnu sina YM-UMI tahun 2010 sebanyak $15 \%$, tahun 2011 sebanyak 12,87\% dan pada tahun 2012 sebanyak 10,18\%. Penelitian serupa juga dilakukan oleh Mardiana (2014) dimana didapatkan data turnover perawat di RS Dhuafa Bogor periode januari - desember 2013 sebesar 13\%. Begitu juga di rumah sakit Atmajaya Jakarta menurut Muliana (2013) didapat data turnover perawat dari tahun 2009 sampai tahun 2012, pada tahun 2009 persentase turnover sebesar 17,3\%, tahun 2010 sebesar 16,2 \%, tahun 2011 sebesar 12,8\% dan tahun 2012 sebesar 30,9\%.

Sementara berdasarkan penelitian Muhammad fauzan (2016) di Rumah sakit Umum Queen Latifa terhitung sejak tahun 2012 sampai 2015 tingkat turnover tenaga medis dan paramedis cukup tinggi, lebih dari $10 \%$ dengan rata - rata $18,06 \%$. Dalam penelitian Rukiah Lubis (2012) di ruang rawat inap Rumah sakit umum Zahirah didapat angka turnover perawat rawat inap sebanyak 40\%. Begitu juga dari hasil penelitian alifiyah (2013) didapat data turnover perawat di Brawijaya Women and Children Hospital sebesar 27,3\%, tingginya angka turnover di rumah sakit tersebut disebabkan oleh tingginya turnover intention perawat untuk keluar dari rumah sakit dimana keinginan tersebut dipengaruhi oleh kepuasan kerja. Turnover intention merupakan kadar atau intensitas dari keinginan untuk keluar dari perusahaan.

Masalah turnover ini akan berdampak pada kekurangan tenaga keperawatan yang pada akhirnya akan berdampak buruk pada pelayanan di Rumah sakit, pasien kurang tertangani dengan baik juga berdampak kelelahan pada tenaga perawat yang ada karena beban kerja bertambah, sehingga akan menciptakan dan meningkatkan angka turnover perawat kembali. Kondisi turnover perawat juga menjadi tantangan yang serius terhadap efisiensi dan efektivitas pelayanan kesehatan. Turnover keperawatan merupakan masalah penting bagi semua lembaga pelayanan kesehatan, dan menjadi masalah utama yang mempengaruhi kinerja dan profitabilitas organisasi kesehatan. Pada dasar nya tidak ada rumah sakit yang dapat menghindari terjadinya turnover perawat, namun jika angka kejadian turnover tinggi dan tidak segera ditekan dikhawatirkan berdampak pada pelayanan dan menjadi permasalah di rumah sakit secara keseluruhan. Banyak faktor yang mempengaruhi terjadinya turnover, salah satunya faktor yang berkontribusi terhadap turnover yaitu kepuasan kerja (Cho, et all, 2012). Berdasarkan penelitian Fauzan (2016) di rumah sakit umum Queen Latifa dari hasil survey didapat ada beberapa faktor yang mempengaruhi turnover, survey yang dengan angka tertinggi adalah karena ketidakpuasan kerja. Turnover perawat menjadi tantangan yang serius terhadap efisiensi dan efektivitas pelayanan kesehatan. Hasil survey terhadap 100 orang perawat pada suatu rumah sakit besar di Singapura menunjukkan bahwa salah satu penyebab turnover perawat adalah kepuasan kerja. Penelitian terdahulu menunjukkan bahwa salah satu faktor yang paling sering menyebabkan perawat meninggalkan rumah sakit adalah terkait faktor kepuasan kerja yang rendah (Tzeng, 2002; Hayes et al., 2006; Faris et al., 2010; Cho et al., 2012).Mobley (1986, dalam Siagian, 2012) menemukan bahwa secara umum karyawan yang tidak puas akan meninggalkan pekerjaannya.

Kepuasan kerja adalah keadaan emosi senang atau emosi positif yang berasal dari penilaian atau pengalaman kerja seseorang (Luthans, 2011). Menurut Triatna (2015) Kepuasan kerja adalah keadaan emosional seseorang terhadap pekerjaannya, apakah ia menyenangi pekerjaan tersebut atau tidak. Defenisi lain yang dikemukakan oleh Kinicki dan Fugate (2012) dalam Kaswan (2015) menyatakan "Job satisfaction is an affective or emotional response towards various facets of one's job", maksudnya kepuasan kerja merupakan tanggapan afektif atau emosi terhadap berbagai fase pekerjaan seseorang. Kepuasan karyawan dapat membantu dalam memaksimalkan profitabilitas perusahaan dalam jangka panjang melalui empat cara, karena karyawan yang puas cenderung bekerja dengan mutu yang lebih tinggi, bekerja dengan lebih produktif, bertahan lama dalam perusahaan dan dapat menciptakan pelanggan yang puas.

Faktor kepuasan kerja menjadi faktor yang paling mempengaruhi kecenderungan dan keputusan karyawan untuk keluar dari tempat kerjanya. Regeb et all (2013) menyatakan bahwa kepuasan kerja memiliki dampak lebih besar terhadap turnover, dibandingkan dengan kinerja pekerjaan atau komitmen organisasi. Penelitian 
serupa dilakukan oleh Andini (2006) yang menyatakan bahwa keinginan berpindah atau keluarnya seseorang juga terkait dengan kepuasan kerja. Nugroho (2012) dalam penelitiannya diperoleh hasil bahwa kepuasan kerja merupakan salah satu faktor yang sangat berpengaruh terhadap keinginan untuk keluar.

Robbins \& Judges dalam Kaswan (2015) membagi empat cara seorang karyawan mengungkapkan ketidakpuasannya dalam bekerja, yaitu exit, voice, neglect, dan loyalty. Exit atau keluar yaitu perilaku yang bertujuan untuk meninggalkan organisasinya, termasuk mencari posisi baru dan mengundurkan diri. Selain itu ketidakpuasan kerja juga berdampak pada loyalitas karyawan, turnover yang tinggi. Keadaan ini jika tidak segera di perhatikan bisa menyebabkan tingginya angka turnover perawat. Adapun faktor - faktor yang mempengaruhi kepuasan kerja adalah pekerjaan itu sendiri (work it self), gaji (pay), hubungan dengan atasan (supervision), hubungan dengan teman sekerja (co-workers), dan kesempatan promosi (promotion opportunities) (Badeni,2014).

Beberapa penelitian tentang kepuasan kerja perawat di Internasional dan di Indonesia, antara lain penelitian Jafar et al (2013) di Teheran tingkat tertinggi ketidakpuasan perawat dalam bekerja adalah gaji dan tunjangan $(90,9 \%)$ dan pengawasan atau supervisi $(85 \%)$. Penelitian serupa oleh Hua et al (2015) di rumah sakit umum China juga demikian dengan hasil nilai tertinggi adalah hubungan dengan rekan kerja $3,94 \pm 0,45$. Sedangkan penelitian yang Dilakukan oleh Feni, dkk (2013) di RSUP Prof. Dr. R. D. Kandou Manado hasil penelitian supervisi 31,6\% kurang baik, pekerjaan itu sendiri 39,5\% kurang baik.

Masalah turnover juga dialami oleh salah satu rumah sakit swasta di Pekanbaru yakni Rumah Sakit Awal Bros Panam. Berdasarkan hasil studi pendahuluan yang dilakukan peneliti melalui teknik wawancara dengan pihak SDM Rumah Sakit Awal Bros Panam pada tanggal 10 Februari 2016, didapatkan data bahwa sejak Rumah Sakit Awal Bros Panam berdiri 22 Januari 2014, angka turnover perawat cukup tinggi dimana tingkat turnover perawat selama periode januari 2015 - desember 2015 sebesar $13,1 \%$, dan pada periode Januari 2016 Desember 2016 sebesar 11,6\%. Angka ini cukup tinggi karena menurut Gillies dalam muliana
(2013), angka turnover normalnya 5-10\% per tahunnya, dikatakan tinggi apabila lebih dari $10 \%$. Turnover biasanya merupakan salah satu pilihan terakhir bagi seorang perawat apabila dia mendapati kondisi kerjanya sudah tidak sesuai lagi dengan apa yang diharapkannya.

Adapun penyebab turnover perawat di rumah sakit Awal Bros Panam bervariasi, seperti ikut suami, pulang kampung, habis masa kontrak, tidak diperpanjang kontrak dan ada rasa tidak puas dalam bekerja (seperti, ketidak puasan dalam gaji, dan dalam kesempatan promosi). Berdasarkan hasil survey kepuasan kerja yang pernah dilakukan pihak SDM rumah sakit awal bros panam di tahun 2015 pada staff perawat, didapatkan data $6,89 \%$ mengatakan tidak puas, $22,1 \%$ yang mengatakan kurang puas, $48 \%$ mengatakan cukup puas dan 23,01 \% yang mengatakan puas.

Berdasarkan fenomena dan teori diatas maka fokus dari penelitian ini adalah "Hubungan kepuasan kerja dengan turnover perawat di Rumah Sakit Awal Bros Panam tahun 2017”.

\section{METODE}

Desain penelitian yang digunakan pada penelitian ini adalah deskriptif korelatif dengan pendekatan cross sectional. Dalam penelitianini populasinya adalah seluruh perawat pelaksana Rumah Sakit Awal Bros Panam yang berjumlah 154 Orang. Pengambilan sampel yang digunakan adalah total sampling dengan memperhatikan kriteria sampel yang telah ditentukan sehingga jumlah sampel yang ditetapkan adalah sebanyak 72 responden

\section{HASIL PENELITIAN}

Berdasarkan penelitian didapatkan hasil sebagai berikut:

\section{A. ANALISA UNIVARIAT}

Analisa univariat dalam penelitian ini adalah karakterstik responden, gambaran kepuasan kerja dan kemungkinan turnover terdiri dari: 
1. Karakteristik Resonden

Tabel 4.5

Karakteristik Perawat di RSAB Panam Tahun $2017(\mathrm{n}=72)$

\begin{tabular}{|c|c|c|}
\hline \multirow{2}{*}{ Karakteristik perawat } & Jumlah & Persentase \\
\hline & $\mathrm{f}$ & $\%$ \\
\hline \multicolumn{3}{|l|}{ 1. Jenis Kelamin } \\
\hline a. Perempuan & 60 & 83,3 \\
\hline b. Laki-laki & 12 & 16,7 \\
\hline Total & 72 & 100 \\
\hline
\end{tabular}

2. Usia

\begin{tabular}{lll} 
a. $22-25$ Tahun & 48 & 66,7 \\
b. $26-32$ Tahun & 24 & 33,3 \\
\hline Total & 72 & 100
\end{tabular}

3. Pendidikan

$\begin{array}{ccc}\text { a. D3 } & 19 & 26,4 \\ \text { b. Ners } & 53 & 73,6 \\ \text { Total } & 72 & 100\end{array}$

4. MasaKerja

\begin{tabular}{lcc} 
a. 0-1 Tahun & 32 & 44,4 \\
b. 1-2 Tahun & 32 & 44,4 \\
c. 2 Tahun & 8 & 11,2 \\
\hline Total & 72 & 100
\end{tabular}

5. Status Pernikahan

\begin{tabular}{lcc} 
a. Menikah & 7 & 9,7 \\
b. Belum & 65 & 90,3 \\
Menikah & & \\
\hline Total & 72 & 100 \\
\hline
\end{tabular}

Hasil analisis pada tabel 4.5 menunjukkan bahwa dari 72 perawat mayoritasnya adalah perempuan $(83,3 \%)$, berusia $22-25$ tahun $(66,7 \%)$, tingkat pendidikan Ners $(73,6 \%)$, masa kerja 0-1 tahun (32\%) dan 1-2 tahun (32\%) dengan status belum menikah (90,3\%).

2. Kepuasan kerja

Tabel 4.6

Kepuasan kerja di RSAB Panam Tahun 2017 $(n=72)$

\begin{tabular}{lcc}
\hline \multirow{2}{*}{ Kepuasan Kerja } & Jumlah & Persentase \\
\cline { 2 - 3 } & $\mathrm{f}$ & $\%$ \\
\hline Tidak Puas & 42 & 58,3 \\
Puas & 15 & 20,8 \\
Sangat Puas & 15 & 20,8 \\
\hline \multicolumn{1}{c}{ Total } & 72 & 100 \\
\hline
\end{tabular}

Hasil analisis pada tabel 4.6 menunjukkan bahwa dari 72 perawat didapatkan data bahwa perawat yang tidak puas bekerja di RSAB panam sebanyak 42 orang $(58,3 \%)$.

\section{Turnover}

Tabel 4.7

Turnover Perawat di RSAB Panam Tahun 2017 $(n=72)$

\begin{tabular}{ccc}
\hline Turn Over & Jumlah & $\begin{array}{c}\text { Persentas } \\
\mathrm{e}\end{array}$ \\
\cline { 2 - 3 } & $\mathrm{f}$ & $\%$ \\
\hline Rendah & 30 & 41,7 \\
Tinggi & 42 & 58,3 \\
\hline Total & 72 & 100 \\
\hline
\end{tabular}

Hasil analisis pada tabel 4.7 menunjukkan bahwa dari 72 perawat didapatkan data bahwa perawat yang tidak puas bekerja di RSAB panam sebanyak 42 orang $(58,3 \%)$ dan turn over perawat saat ini adalah tinggi sebanyak 42 perawat $(58,3 \%)$.

\section{B. ANALISA BIVARIAT}

Tabel 4.8

Hubungan Kepuasan Kerja dengan Turnover Perawat di Rumah Sakit Awal Bros Panam tahun 2017 $(\mathrm{n}=72)$

\begin{tabular}{|c|c|c|c|c|c|c|c|c|}
\hline \multirow{3}{*}{ No } & \multirow{3}{*}{$\begin{array}{c}\text { Kepuasan } \\
\text { Perawat }\end{array}$} & \multicolumn{4}{|c|}{ Turn Over } & \multirow{2}{*}{\multicolumn{2}{|c|}{ Total }} & \multirow{3}{*}{$\begin{array}{c}p \\
\text { val } \\
\text { ue }\end{array}$} \\
\hline & & \multicolumn{2}{|c|}{ Rendah } & \multicolumn{2}{|c|}{ Tinggi } & & & \\
\hline & & $f$ & $\%$ & $f$ & $\%$ & $f$ & $\%$ & \\
\hline 1 & $\begin{array}{l}\text { Tidak } \\
\text { Puas }\end{array}$ & 23 & $\begin{array}{c}76, \\
7\end{array}$ & 19 & $\begin{array}{c}45, \\
2\end{array}$ & 42 & $\begin{array}{c}58, \\
3\end{array}$ & \\
\hline 2 & Puas & 4 & $\begin{array}{c}13 \\
3\end{array}$ & 11 & $\begin{array}{c}26, \\
2\end{array}$ & 15 & $\begin{array}{c}20 \\
8\end{array}$ & 0,0 \\
\hline 3 & $\begin{array}{l}\text { Sangat } \\
\text { Puas }\end{array}$ & 3 & 10 & 12 & $\begin{array}{c}28 \\
6\end{array}$ & 15 & $\begin{array}{c}20 \\
8\end{array}$ & 27 \\
\hline & Jumlah & 30 & $\begin{array}{c}10 \\
0\end{array}$ & 42 & 100 & 72 & 100 & \\
\hline
\end{tabular}

Hasil analisis pada tabel 4.8 menunjukkan bahwa dari 42 perawat yang merasa tidak puas didapatkan 19 perawat 
$(45,2 \%)$ yang memiliki keinginan untuk turnover yang tinggi, sedang kandari 15 perawat yang hanya merasa puas didapatkan 11 perawat (26,2\%) yang memiliki keinginan untuk turnover yang tinggi dan dari 15 perawat yang sangat puas masih terdapat 12 perawat $(28,6 \%)$ yang juga memiliki keinginan untuk turnover yang tinggi. Berdasarkan uji statistic chi square, di dapatkan nilai $p$ value $=0,027, \dot{\alpha}<0,05$, maka terdapat hubungan kepuasan kerja dengan turnover perawat di Rumah Sakit Awal Bros Panam tahun 2017.

\section{PEMBAHASAN}

Masalah turnover yang tinggi juga dialami oleh salah satu rumah sakit swasta di Pekanbaru yakni Rumah Sakit Awal Bros Panam. Berdasarkan hasil studi pendahuluan yang dilakukan peneliti melalui teknik wawancara dengan pihak SDM Rumah Sakit Awal Bros Panam pada tanggal 10 Februari 2016, didapatkan data bahwa sejak Rumah Sakit Awal Bros Panam berdiri 22 Januari 2014, angka turnover perawat cukup tinggi dimana tingkat turnover perawat selama periode januari 2015 desember 2015 sebesar 13,1\%, dan pada periode Januari 2016 - Desember 2016 sebesar 11,6\%.

Angka turnover perawat RSAB Panam ini cukup tinggi karena menurut Gillies dalam Muliana (2013), angka turnover normalnya 5$10 \%$ per tahunnya, dikatakan tinggi apabila lebih dari 10\%. Turnover biasanya merupakan salah satu pilihan terakhir bagi seorang perawat apabila dia mendapati kondisi kerjanya sudah tidak sesuai lagi dengan apa yang diharapkannya. Dari hasil suvey work Asia yang dikutip oleh Amirullah (2011) dalam penelitian Alfiyah (2013), pada tahun 2007/2008 survey yang dilakukan konsultan SDM Watson Wyatt di 11 negara Asia-Pasifik, termasuk Indonesia mengungkapkan 51\% karyawan di Indonesia melakukan pindah kerja atau keluar dari satu perusahaan karena rendahnya tingkat kepuasannya dalam bekerja. Sampai saat ini belum terdapat data pasti yang membahas masalah mengenai jumlah kasus turnover di dunia. Kasus turnover juga merupakan kasus yang cukup banyak terjadi dirumah sakit swasta di Indonesia.

Berdasarkan hasil penelitian didapatkan data bahwa dari 42 perawat yang merasa tidak puas didapatkan 19 perawat $(45,2 \%)$ yang memiliki keinginan untuk turnover yang tinggi, sedangkan dari 15 perawat yang hanya merasa puas didapatkan 11 perawat $(26,2 \%)$ yang memiliki keinginan untuk turnover yang tinggi dan dari 15 perawat yang sangat puas masih terdapat 12 perawat $(28,6 \%)$ yang juga memiliki keinginan untuk turnover yang tinggi. Berdasarkan uji statistik chi square, didapatkan nilai $p$ value $=0,027, \alpha<0,05$, maka terdapat hubungan kepuasan kerja dengan turnover perawat di Rumah Sakit Awal Bros Panam tahun 2017.

Berdasarkan hasil survey kepuasan kerja yang pernah dilakukan pihak SDM rumah sakit awal bros panam di tahun 2015 pada staff perawat, didapatkan data $6,89 \%$ mengatakan tidak puas, $22,1 \%$ yang mengatakan kurang puas, $48 \%$ mengatakan cukup puas dan $23,01 \%$ yang mengatakan puas. Adapun penyebab turnover perawat di rumah sakit Awal Bros Panam bervariasi, seperti ikut suami, pulang kampung, habis masa kontrak, tidak diperpanjang kontrak dan ada rasa tidak puas dalam bekerja (seperti, ketidak puasan dalam gaji, dan dalam kesempatan promosi).

Berdasarkan hasil kuesioner diketahui bahwa ketidakpuasan kerja perawat dalam penelitian ini lebih banyak pada pertanyaan seputar gaji dimana perawat saat ini merasa RS belum memberikan gaji sesuai dengan apa yang sudah dikerjakan $(45,9 \%)$, perawat merasa kurang puas dengan fasilitas berobat yang diberikan oleh perusahaan $(16,7 \%)$, perawat merasa gaji di RS lain lebih baik dibandingkan RSAB Panam $(29,2 \%)$ dan perawat merasa gajinya tidak cukup adil jika dibandingkan dengan rekan kerjanya yang lainnya $(34,7 \%)$.

Banyak hal yang mempengaruhi kepuasan kerja seorang perawat, gaji, usia, pendidikan dan pendidikan merupakan hal yang mempengaruhi kepuasan kerja perawat. Hal ini terlihat bahwa dari 72 perawat, $66,7 \%$ diantaranya berusia $\leq 25$ tahun. Perawat yang berusia muda masih mencoba mencari lingkungan pekerjaan yang cocok dan nyaman buat mereka serta dengan dengan usia yang muda memudahkan mereka untuk berpindah kerja dari satu tempat ke tempat yang lain untuk mencari pengalaman kerja dan mereka belum mempunyai tanggung jawab yang besar dibandingkan dengan perawat senior. 
Masa kerja mempengaruhi keinginan untuk turnover dimana seseorang yang terus melakukan pekerjaan yang sama dalam waktu yang lama akan merasa bosan dan tidak puas sehingga lebih besar kemungkinannya untuk keluar dari pekerjaan. Rumah sakit hendaknya dapat menyesuaikan jumlah pekerjaan dan tanggung jawab yang dapat diberikan kepada perawat. Bagi perawat yang masa kerjanya lama (senioritas) maka kemungkinan untuk turnover akan semakin kecil.

Tidak hanya itu saja, tidak dapat disangkal bahwa salah satu faktor penyebab timbulnya keinginan pindah kerja adalah ketidakpuasan pada tempat bekerja sekarang. Karakteristik pekerjaan berupa jumlah pekerjaan yang diberikan, tingkat tanggung jawab dan kebebasan yang diberikan dalam melakukan pekerjaan, keragaman dan kemudahan pekerjaan sangat menentukan tingkat kepuasan seorang perawat dalam bekerja yang akhirnya akan berdampak pada keinginan dia untuk tetap tinggal atau pergi dari organisasi tempat ia bekerja.

Hasil penelitian ini sesuai dengan penelitian Alfiyah (2013) di Brawijaya Women and Children Hospital Jakarta dimana ditemukan bahwa perawat yang tidak puas dengan pekerjaan dan memiliki niat untuk keluar lebih banyak dibandingkan dengan perawat yang menyatakan puas terhadap pekerjaan dengan nilai $p$ value $=0.003(0,05)$ maka dapat disimpulkan variabel kepuasan terhadap pekerjaan berhubungan signifikan dengan turnover intention.

Hasil penelitian Anik (2013) turut menyatakan bahwa turnover perawat di rumah sakit Ibnu Sina YM-UMI tahun 2010 sebanyak $15 \%$, tahun 2011 sebanyak 12,87\% dan pada tahun 2012 sebanyak 10,18\%. Penelitian serupa juga dilakukan oleh Mardiana (2014) dimana didapatkan data turnover perawat di RS Dhuafa Bogor periode januari - desember 2013 sebesar 13\%. Sementara berdasarkan penelitian Fauzan (2016) di Rumah sakit Umum Queen Latifa terhitung sejak tahun 2012 sampai 2015 tingkat turnover tenaga medis dan paramedis cukup tinggi, lebih dari $10 \%$ dengan rata - rata $18,06 \%$. Dalam penelitian Rukiah (2012) di ruang rawat inap Rumah sakit umum Zahirah didapat angka turnover perawat rawat inap sebanyak $40 \%$.
Setelah dilakukan penelitian tentang " Hubungan kepuasan kerja dengan turnover perawat di Rumah Sakit Awal Bros Panam tahun 2017", dapat disimpulkan:

1. Terdapat 42 orang $(58,3 \%)$ yang tidak puas bekerja di RSAB panam

2. Turnover perawat saat ini adalah tinggi sebanyak 42 perawat $(58,3 \%)$.

3. Berdasarkan uji statistik chi square, didapatkan nilai $p$ value $=0,027, \alpha<0,05$, maka terdapat hubungan kepuasan kerja dengan turnover perawat di Rumah Sakit Awal Bros Panam tahun 2017

\section{DAFTAR PUSTAKA}

Alfiyah. (2013). Faktor - faktor yang berhubungan dengan turn over intention perawat di Brawijaya Women and Children Hospital Jakarta. Peminatan Manajemen Pelayanan Kesehatan Program Studi Kesehatan Masyarakat Fakultas Kedokteran dan Ilmu Kesehatan Universitas Islam Negeri Syarif Hidayaullah Jakarta. http://repository.uinjkt.ac.id/dspace/bitstr eam/.../1/ Alfiyah-fkik.pdf

Amirullah (2011). Tetap Bijak Saat Pegawai Dibajak. Diperoleh pada tanggal 25 Agustus 2017 dari http://www.tempo.co/read/new/2011/09/2 5/174358095/ tetap-bijak-saat-pegawaidibajak

Aryanto, B.(2011). Faktor-Faktor yang Berhubungan dengan Kecendrungan Turnover Perawat di Rumah Sakit Islam "Ibnu Sina" Yarsi Sumbar Bukit Tinggi. Skripsi strata satu Universitas Andalas, Padang.

Azwar, A \& Prihartono, J (2014). Metodologi Penelitian Kedokteran \& Kesehatan Masyarakat. Jakarta: Binarupa Aksara.

Badeni. (2014). Kepemimpinan \& Perilaku Organisasi. Bandung: Alfabeta.

Dahlan.S.M, (2014. Statistik Untuk Kedokteran dan Kesehatan. Jakarta: Epidemiologi Indonesia. 
Fauzan, M (2016). Pengaruh Kepuasan Kerja Dan Komitmen Organisasi Terhadap Turnover Intention (Studi pada Karyawan Medis Rumah Sakit Umum Queen Latifa di Kab. Sleman). Skripsi strata satu, Universitas Negeri Yogyakarta, Yogyakarta.

Hasibuan, M.S.P (2016). Manajemen Sumber Daya Manusia. Jakarta: Bumi Aksara

Kaswan, (2015). Sikap Kerja: Dari Teori dan Implementasi Sampai Bukti, Bandung: Alfabeta.

Khan, A. H., dan Aleem, M. (2014). Impact of Job Satisfaction on Employee Turnover: An empirical study of Autonomous Medical Institutions of Pakistan. Journal of International Studies, 7(1), 122-132. Pakistan.

Kurniadi, A. (2013). Manajemen Keperawatan dan Prospektifnya: Teori, Konsep dan Aplikasi. Jakarta: FKUI.

Kuswadi. (2014). Cara Mengukur Kepuasan Karyawan. Jakarta (ID) : PT Elex Media Komputindo.

Langitan, R. E. (2010). Faktor-faktor yang mempengaruhi kejadian turnover perawat pelaksana. Tesis. Universitas Indonesia, Jakarta.

Luthans, Fred. (2006). Perilaku Organisasi. Edisi 10. Yogyakarta: Andi.

Mahdi, Zaid, Roslan, dan Sakat. (2012). The Relationship Between Job Satisfaction and Turnover Intention Among The Employee In XYZ Sdn. Bhd, Malaysia. American Journal of Applied Sciences, 9(9), 1518-1526.

Mardalis. (2014). Metode Penelitian : Suatu Pendekatan Proposal. Jakarta: Bumi Aksara.

Mardiana, I, dkk. (2014). Hubungan kepuasan kerja dengan turnover Intentions pada perawat Rumah Sakit Dhuafa. Manajemen IKM IPB, Bogor, 119 - 130.

Mathis dan Jackson. (2011). Human Resource Management. Jakarta: Salemba Empat.

MiyounG, K, Eun, J. K, Sujin, C. (2016). A Study of Relationship between Nursing Performance, Job Satisfaction, and Organizational Commitment. Ewha Womans University, Advanced Science and Technology Letters Vol.128 (Healthcare and Nursing.

Muliana, S. (2013). Faktor-Faktor yang Mempengaruhi Keinginan Pindah Kerja Perawat Rumah Sakit Atma Jaya. Tesis Program Magister Manajemen Universitas Esa Unggul Jakarta

Notoatmodjo, S. (2010). Metode penelitian kesehatan. Jakarta: Rineka Cipta.

Nursalam (2011). Manajemen Keperawatan aplikasi dalam praktik keperawatan professional. Jakarta: Salemba Medika.

O Brien-Pallas, dkk. (2010). Management System Information. McGraw Hill, New York.

Puput, W. (2015). Pengaruh Kepuasan Kerja Dan Komitmen Organisasi Terhadap Organizational Citizenship Behavior Perawat Rumah Sakit Islam Yogyakarta. Skripsi Strata satu, Universitas Negeri Yogyakarta, Yogyakarta.

Rageb, M,A., Abd E.S.EM, El-Samadicy A, Farid S. (2013). Organizational Commitment, Job Satisfaction and Job Performance as a Mediator between Role Stressors and Turnover Intentions a Study from an Egyptian Cultural Perspective. TheBusiness \& Management Review. 3 (2): 51-73.

Robbins, S. P., \& Judge, T. A. (2008). Perilaku organisasi, Edisi 12. Jakarta : Salemba Empat. 
Rukiah, L. (2012). Analisis faktor - faktor yang mempengaruhi turnover perawat rawat inap di RSU Zahirah. Diperoleh pada tanggal 25 Agustus 2017 dari http://lib.ui.ac.id/naskahringkas/2015-

09/S47582-Rukiah Lubis

Saining, J. P. G., Hamzah, A., \& Idar. (2011). Analisis faktor keinginan pindah kerja(intention turnover) perawat di rumah sakit umum daerah (RSUD) kabupaten Buol provinsi Sulawesi Tengah.

Santoso, I. (2013). Manajemen data Untuk analisis data penelitian kesehatan. Yogyakarta: Gosyen Publishing.

Setiawan, T. (2007). Hubungan antara karakteristik individu dengan kepuasan kerja perawat pelaksana di $R S$ Banyumanik. Diperoleh pada tanggal 11 Agustus 2017 dari http://digilib.unnes.ac.id.

Siswanto dan Sucipto. (2008). Teori dan Perilaku Organisasi. Malang: UIN Malang Press.

Sopiyudin, M. D. (2013). Statistik untuk kedokteran dan kesehatan. Jakarta: Salemba Medika

Tahsinia, N. (2013). Faktor-faktor yang berhubungan dengan kepuasan kerja perawat di Rumah Sehat Terpadu Parung Bogor. Skripsi manajemen pelayanan kesehatan Program Studi Kesehatan Masyarakat Fakultas Kedokteran dan Ilmu Kesehatan Universitas Islam Negeri Syarif Hidayatullah, Jakarta.

Wibowo, A. E. (2012). Aplikasi praktis spss dalam penelitian. Yogyakarta: Gava Medika.

Wolo, P. D. (2015). Analisis faktor-faktor yang mempengaruhi kepuasan kerja perawat. Program studi mahister manajemen program pasca sarjana: Universitas Muhammadiyah Surakarta. Diperoleh pada tanggal 13 Agustus 2017 dari https://

eprints.ums.ac.id/39144/20/NASKAH\%2

520PUBLIKASI.pdf \&prev=search 